\title{
SUSTAINABLE TRANSPORT IN ROMANIA VS. EUROPEAN UNION. ANALYSIS OF ROAD TRANSPORT SYSTEM FROM THE SUSTAINABLE TRANSPORT PERSPECTIVE
}

Clitan Andrei - Florin, Asistent Dr. Ing., Technical University of Cluj-Napoca, Faculty of Civil Engineering, e-mail: Andrei.CLITAN@infra.utcluj.ro

\section{Rezumat}

Durabilitatea este un termen folosit tot mai des în ultima vreme, acesta bazându-se pe trei tipuri de factori: sociali, economici și de mediu. Sistemele durabile de transport duc la creșterea coeziunii sociale, reduc problemele de mediu și ajută la crearea unei economii mai eficiente. Transportul durabil constă într-un sistem complex, care este proiectat pentru a asigura nevoile de mobilitate ale generațiilor prezente, fără a deteriora factorii de mediu și de sănătate. Prin îmbunătățirea eficienți energetice și reducerea consumului de materiale, acesta trebuie să fie capabil să îndeplinească în condiții optime, nevoia de mobilitate pentru generațiile viitoare. Sistemul de transport actual din țara noastră nu are un caracter de durabilitate.

Acest articol încearcă să identifice o serie de probleme și disfuncționalități ale sistemelor de transport, din perspectiva unui sistem de transport durabil. Pentru alinierea la standardele Uniunii Europene este necesar să se ia măsuri pentru îmbunătățirea actualului sistem de transport.

Soluțiile propuse trebuie să fie soluții ecologice, social și economic viabil echitabile. Există o serie de beneficii prin implementarea unui astfel de sistem, atât directe, cât și indirecte: un cost redus de transport, confort sporit, mai puțină poluare a mediului, reducerea accidentelor rutiere. Durabilitatea rețelelor de drumuri este atât o provocare cât și o necesitate a zilelor noastre.

Cuvinte cheie: durabilitate, sisteme de transport, siguranța circulației

\begin{abstract}
Sustainability is a term used more often lately, based on three factors: social, economic, and environmental. Sustainable transport systems increase social cohesion, reduce environmental problems and help create a more efficient economy. Sustainable transport consists in a complex system that is designed to ensure mobility needs of present generations without damaging the environment and health factors. By improving energy and material consumption, it must be capable to satisfy in optimum conditions the need for mobility for future generations. The current transportation system has not a character of sustainability.
\end{abstract}


ROMANIAN JOURNAL

OF TRANSPORT INFRASTRUCTURE

Clitan Andrei - Florin,

Sustainable transport in Romania vs. European Union. Analysis of road transport system from the sustainable transport perspective

This article attempts to identify a series of problems and shortcomings of transportation system, from the perspective of a sustainable transport system. In order to align with EU standards it is necessary to take measures to improve the existing transport system The proposed solutions must be environmentally friendly solutions, socially equitable and economically viable.

There are a number of benefits by implementing such a system, both direct and indirect: a low cost of transport, increased comfort, less environmental pollution, road accidents reduction.

Road networks sustainability is both a challenge and a necessity nowadays.

Keywords: sustainability, transportation systems, traffic safety

\section{TRANSPORT SYSTEMS}

Transport systems represent all the facilities and transport equipment, usually grouped by a certain criterion .

They fall into several types of systems, usually grouped by transport infrastructure :

- $\quad$ Road transport systems;

- $\quad$ Railway transport systems;

- $\quad$ Air transport system;

- $\quad$ River and sea transport systems;

- $\quad$ Pipeline transportation systems.

In turn each transport system consists of:

- Transport infrastructure (road, rail, air corridor, waterways, pipelines and pumping stations);

- Means of transport (vehicles, locomotives - cars, ships, containers) ;

- Systems management and control systems.

Transport activity can be divided into two broad categories: passenger transport and goods transport.

Regarding passenger transport, in the European Union, it is done especially by the road, as seen from Figure 1. 
ROMANIAN JOURNAL

OF TRANSPORT INFRASTRUCTURE

Clitan Andrei - Florin,

Sustainable transport in Romania vs. European Union. Analysis of road transport system from the sustainable transport perspective

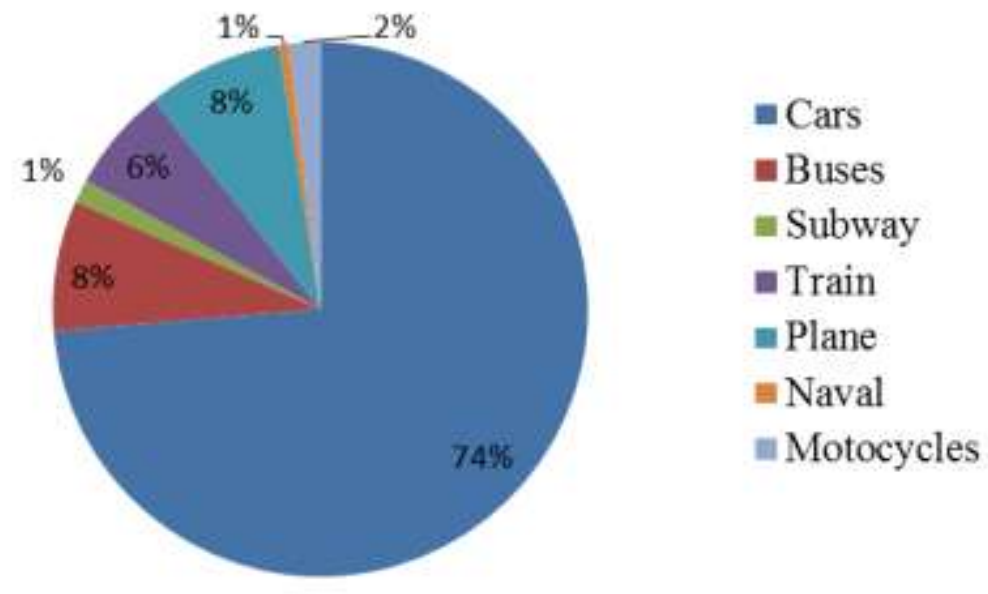

Figure 1. Distribution of passengers by mode of transport in the European Union (2010) [1]

In our country, passenger transport is more oriented thouwards transport using roads. This coupled with the lack of roads and highways network leads to a cluster on the existing roads.

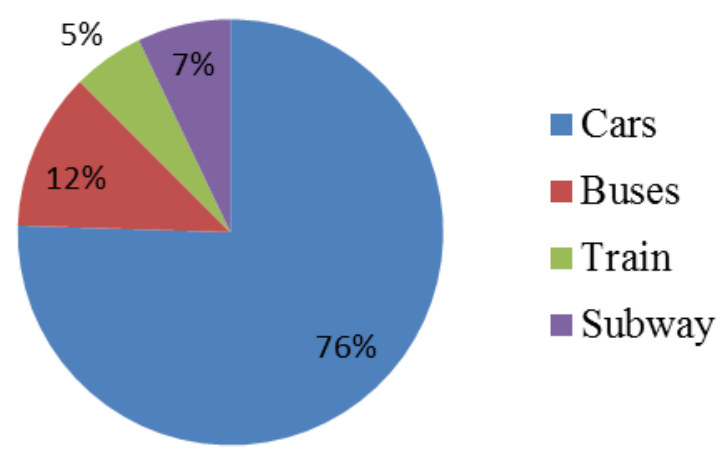

Figure 2. Procentual distribution of passengers depending on the type of transport used in Romania (2010) [1]

The carriage of goods within the European Union it is in excess of 70 percent all done on the road ( Figure 3). 


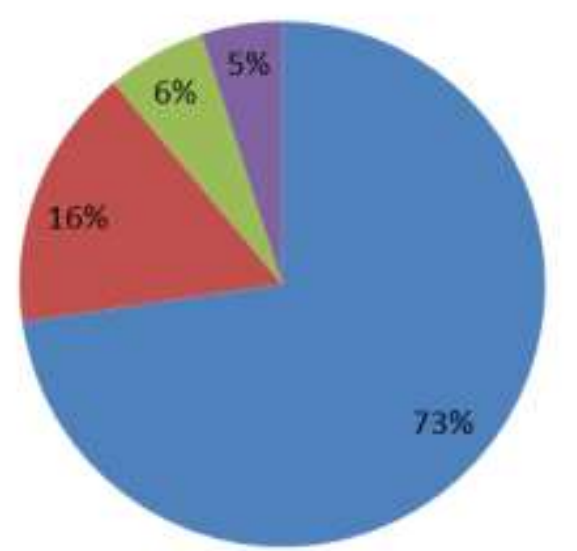

Roads

- Railways

Eivers

aipes

Figura 3. Percentage distribution of goods transport by mode of transport in the European Union (2010) [1]

\section{DURABILITY. SUSTAINABLE TRANSPORT}

Sustainable development involves performing an activity without exhausting the available resources, without destroying the environment.

Transport is an important factor in economic and social development, which must be developed in a sustainable way to not impose significant costs on society, in terms of environmental impact and health [2].

Sustainable transport is a complex system designed to provide mobility for the present needs without damaging environmental factors and health. The efficiency of energy and material consumption must be possible to meet in terms of socio-economic and ecological factors, the optimum need for mobility for future generations [3].

Sustainable transport supports all means of transport through the use of intermodal freight transport. Each mode of transport has advantages and disadvantages, but under certain conditions can become the most favourable. The cheapest means of transport is by ship on river, but not justified at short distances. Road transport has the advantage of "door to door" transport and the railway transport has the advantage of a more capacity than the road transport [4].

Intermodal transport in certain circumstances allows a combination of these different transport modes to achieve in a certain way the advantages of each mode of transport: the mobility of road, the railway capacity, the price of naval or air speed. 
ROMANIAN JOURNAL

OF TRANSPORT INFRASTRUCTURE

Clitan Andrei - Florin,

Sustainable transport in Romania vs. European Union. Analysis of road transport system from the sustainable transport perspective

The main objectives to be achieved in a sustainable transport system are:

- Reducing the environmental impact of transport;

- Improving economic efficiency;

- Reduce accidents and hence the number of deaths and property damage.

\section{ANALYSIS OF ROAD TRANSPORT SYSTEM IN ROMANIA}

Transport is considered a priority in the context of Romania's development plans, given its interdependence with other branches of the national economy, the value of services provided to the population, and its considerable impact on the environment [5].

The road transport is the main transport system used in our country, for the transportation of passengers and goods. Its advantage over other means of transportation, as mentioned before, is that it allows precise delivery of goods to their destination, without the need of transhipment.

One of the main problems of our country is the road transport network's degree of development. The lack of highways along the main routes of transit makes traffic difficult and with relatively low commercial speeds. Romania currently has over $650 \mathrm{~km}$ of highways, but they are not interconnected. On the $4^{\text {th }}$ corridor, the Nadlac - Sibiu sector, only the following sections are completed: Arad - Timisoara and Deva - Sibiu. The remaining sections are in different stages of execution. On the Transylvania highway (A3), the only completed section is Gilau - Campia Turzii, having a length of $52 \mathrm{~km}$. This section operates more like a bypass to Cluj-Napoca city for traffic coming from the west through the Bors Customs.

At the capital level there is no bypass highway that links the three highways entering Bucharest. This makes the traffic in the area difficult to carry out.

However, if we compare the density of the highways network $/ 100 \mathrm{~km}^{2}$ from Romania compared to other EU countries (see Figure 4), we observe a big difference between our country, where we have approximately $0.3 \mathrm{~km}$ highway $/ 100 \mathrm{~km}^{2}$, and the more developed countries from the EU that have over $2 \mathrm{~km}$ of reported highways at $100 \mathrm{~km}^{2}$ [1]. Belgium, Netherlands and Luxembourg have the highest density of highways. 


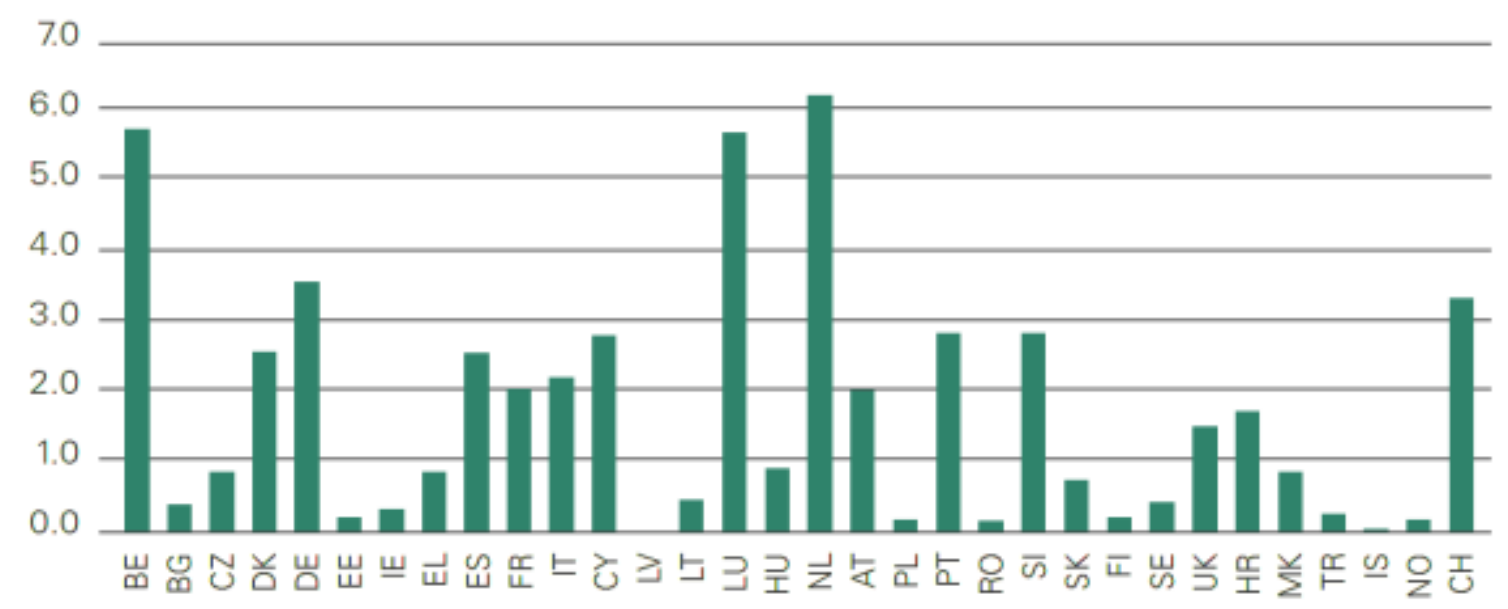

Figure 4. The density of highways network in the European Union countries (2010) [1] $\left(\mathrm{km} / 100 \mathrm{~km}^{2}\right)$

In the absence of highways, the national and European main roads in our country become quite crowded. In order to achieve an efficient transport system with a cost as low as possible, and with little impact on the environment, it is necessary to construct bypasses for cities. By this measure, the heavy traffic is removed from urban areas, resulting in a city more "airy" both in terms of pollution and traffic [3].

The technical state of roads is also a factor that influences the sustainable transport in a negative way. Transport carried out on inappropriate runways increases pollution through increased exhaust emissions, increases transport costs by increasing fuel consumption, increases maintenance costs and increases vehicle travel times.

Another factor which may define a sustainable transport system is the number of accidents. Of all modes of transport, the road transport is the most dangerous and the most costly one, in terms of life loss. The directly measurable cost of road accidents in Europe is in the order of 45 billion euro. Indirect costs physical damage and psychological damage suffered by victims and their families, are three to four times higher. Aside from this issue human costs are incalculable [5].

EU White Paper, European transport policy elaborated in Brussels in 2001, had as an objective of halving the number of accidents at European level until 2010. Following it, "Towards a European road safety - policy orientations on road safety 2011-2020" was elaborate, that presents European strategies on 
ROMANIAN JOURNAL

OF TRANSPORT INFRASTRUCTURE

Clitan Andrei - Florin,

Sustainable transport in Romania vs. European Union. Analysis of road transport system from the sustainable transport perspective

education and training in road safety, and promotes new technologies to improve road safety [2]

In Figure 5 we have the evolution of the number of accidents involving injuries, both in Europe and in our country. We note that in all 27 EU countries we have a decreased by 25 percent between 2001 and 2010, while in our country we have an increase of 2.29 times. A significant leap occurs in 2004, since until then the slight accidents were not counted in this category in our country [7].

\begin{tabular}{|c|c|c|c|c|c|c|c|c|c|}
\hline & 1990 & 1995 & 2000 & 2005 & 2008 & 2009 & 2010 & \begin{tabular}{c|} 
Evolutie \\
$2000-2010$ \\
$(\%)$ \\
\end{tabular} & $\begin{array}{c}\text { Evolutie } \\
2009-2010 \\
(\%)\end{array}$ \\
\hline EU-27 & $1,487.61$ & $1,420.35$ & $1,491.22$ & $1,326.30$ & $1,239.11$ & $1,188.99$ & 1.115 .25 & -25.21 & -6.20 \\
\hline EU-15 & $1,342.80$ & $1,269.19$ & $1,343.89$ & $1,165.08$ & $1,075.76$ & $1,042.09$ & 981.94 & -26.93 & -5.77 \\
\hline EU-12 & 144.81 & 151.17 & 147.34 & 161.22 & 163.36 & 146.90 & 133.31 & -9.52 & -9.25 \\
\hline RO & 9.71 & 9.12 & 7.89 & 19.82 & 29.31 & 28.61 & 26.00 & 229.51 & -9.15 \\
\hline
\end{tabular}

Figure 5. Evolution of the number of accidents resulting in injuries [1]

Figure 6 shows the evolution of the number of people killed between 2001 and 2010 in the European Union countries. At the European Union level with all 27 states we have a decreased by over 40 percent, approaching the target number proposed in 2001, while in our country we have a reduction in the number of fatalities with only 3 percent in 2010 compared to 2001 .

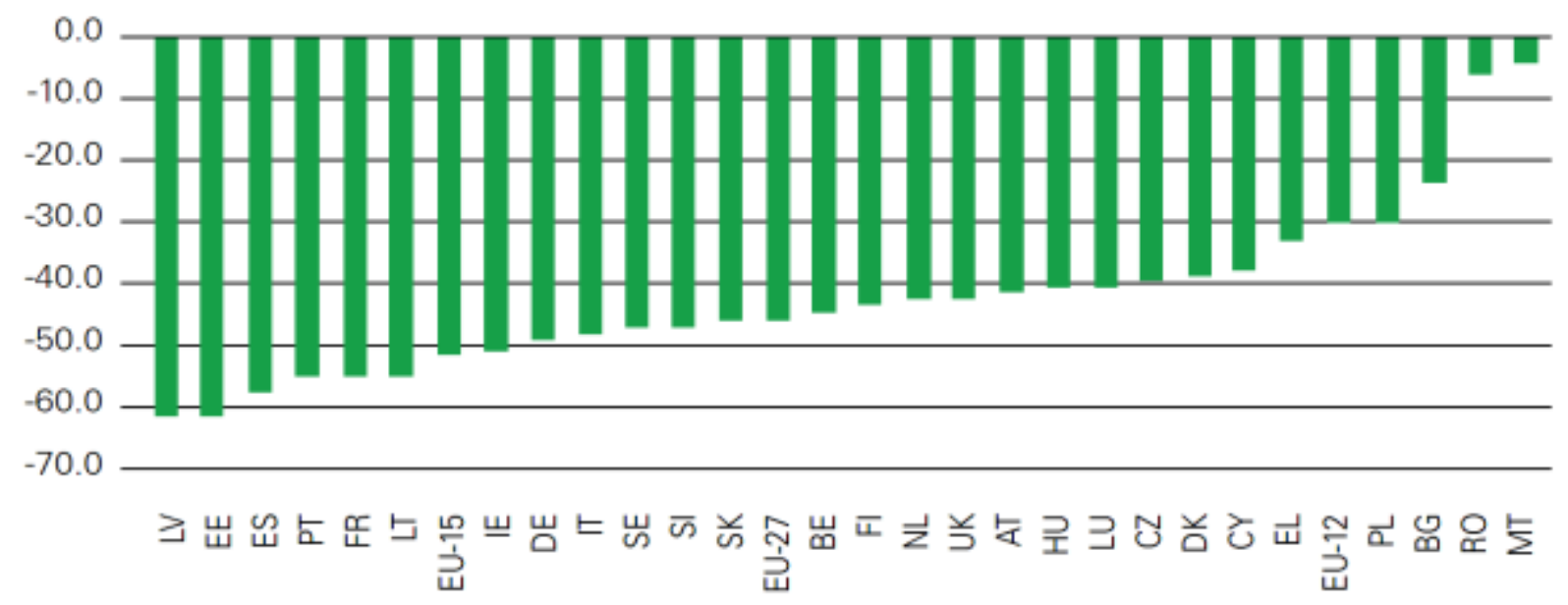

Figure 6. Evolution of the number of people killed between 2001 and 2010 in the countries of the European Union [1] 
ROMANIAN JOURNAL

OF TRANSPORT INFRASTRUCTURE

Clitan Andrei - Florin,

Sustainable transport in Romania vs. European Union. Analysis of road transport system from the sustainable transport perspective

In order to achieve a sustainable transport system it is necessary to reduce the level of pollution. This can be done at the level of freight transport by stimulating intermodal freight transport, by container chassis or by a RO-LA (Road-Rail) system. This type of transport, since is carried out on railways, is more environmentally friendly than the road transport. According to an analysis [8] carried out in our country on the route Glogovat - Bucharest, the need for a subsidy of 55\% from the transport cost for it to be economically viable was revealed, so as to be attractive to transport operators.

\section{CONCLUSIONS}

This paper attempts to identify some of the weaknesses of transport systems in Romania, especially on road transport system in terms of a sustainable transport. The presented article shows that the current transport system in our country is non-sustainable. In order to align with the EU standards measures need to be taken to improve the existing transport system. The proposed solutions must be green solutions, socially equitable and economically viable.

There are a number of long-term benefits obtained through the implementation of such a system, both direct and indirect: a low transport cost, increased comfort, less environmental pollution, and road accidents reduction.

The sustainability of road networks it is both a challenge and a necessity nowadays.

\section{REFERENCES}

[1]. “European Road Statistics”, European Union Road Federation, 2012.

[2]. A. F. CLITAN: "Studii privind dezvoltarea unui sistem de transport durabil”, Teză de doctorat, 2012.

[3]. A.F. CLITAN : "Siguranţa Circulaţiei - element al transportului durabil", Simpozionul Naţional de Siguranţa Circulaţiei, ISBN 978-973-662-481-0, ClujNapoca, 12-13 Noiembrie 2009.

[4]. $\quad$ Strategia pentru transport durabil pe perioada 2007-2013 şi 2020, 2030, Guvernul României, Ministerul Transporturilor, Martie 2008. 


\section{ROMANIAN JOURNAL \\ OF TRANSPORT INFRASTRUCTURE}

Clitan Andrei - Florin,

Sustainable transport in Romania vs. European Union. Analysis of road transport system from the sustainable transport perspective

[5]. Strategia Națională pentru Dezvoltare Durabilă a României, Orizonturi 2013-20202030. Guvernul României Ministerul Mediului si Dezvoltării Durabile, Programul Naţiunilor Unite pentru Dezvoltare Centrul Național pentru Dezvoltare Durabilă București, 2008

6]. A.F. CLITAN: "Evoluţia accidentelor rutiere în România în raport cu Uniunea Europeană” Simpozionul Naţional de Siguranţa Circulaţiei „Siguranţa circulaţiei în actualitate", Cluj-Napoca, ISSN 2069-749X, 3-4 Noiembrie 2011.

[7]. C. TOȘA: "Accident, risc și expunere în siguranța circulației. colectarea și raportarea datelor" Simpozionul Naţional de Siguranţa Circulaţiei „Siguranţa circulaţiei în actualitate", Cluj-Napoca, ISSN 2069-749X, 16-17 Mai 2013.

[8]. Strategia de transport intermodal în România 2020. Ministerul Transporturilor și Infrastructurii, Mai 2011. 